Jurnal Konstruksi Hukum | ISSN: 2746-5055

Vol. 2, No. 1, Januari 2021 Hal. 175-179 | Tersedia online di https://www.ejournal.warmadewa.ac.id/index.php/jukonhum

DOI: https://10.22225/jkh.2.1.2990.175-179

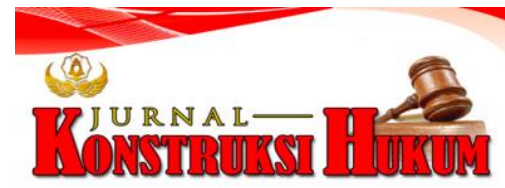

\title{
PERLINDUNGAN HUKUM BAGI PEMEGANG MEREK TERHADAP PEMALSUAN MEREK FASHION
}

\author{
Ni Made Dwi Ari Cahyani, Anak Agung Sagung Laksmi Dewi, Ni Made Sukaryati Karma \\ Fakultas Hukum Universitas Warmadewa, Denpasar-Bali, Indonesia
}

\begin{abstract}
Abstrak
Merek merupakan bentuk dari salah satu kekayaan intelektual yang mempunyai fungsi terhadap peningkatan atau kelancaran perdagangan jasa atau barang bagi yang melaksanakan perdagangan investasi maupun barang. Penelitian ini bertujuan menjelaskan perlindungan hukum bagi pemegang merek terhadap perbuatan pelanggaran pemalsuan merek fashion dan menjelaskan penyelesaian pelanggaran hukom terhadap pemegang merek yang dirugikan akibat pemalsuan merek fashion. Penelitian ini menggunakan metode penelitian hukum normatif yaitu penelitian hukum doktrinal, juga disebut sebagai peneltian perpustakaan dokumen atau studi dokumen. Pendekatan yang digunakan adalah pendekatan perundang-undangan dan konseptual. Data yang digunakan adalah sumer data hukum primer dan sekunder. Hasil penelitian menunjukkan bahwa perlindungan hukum yang ada juga berlaku bagi pemegang merek merupakan perlindungan yang diberikan terhadap subyek hukum dalam bentuk perangkat hukum baik preventif maupun represif. Pelanggaran hukum terhadap pemalsuanmerek diatur didalam Undng-Undang Nomur 20 Tahun 2016 tentang Merek dan Indikasi Geogafis pasal 83 ayat (3) dimana menggunakaan jalur pengadilan Niaga menjadi lembaga dalam mengakhiri sengketa merek, pemalsuan pelanggaran merek terkenal diselesaikan dapat melalui proses jalur hukum pidana dan jalur hukom perdata. Upaya hukom pemengang ha katas merek terhadap perbuatan pelanggaran merek produk Fashion Zara dapat mengajukaan gugatan Pidana dan gugatan perdata terhadap beracara dan/atau juga kerugian dipengadilan naga disesuaikan terhadap ketetapan diatur didalam pasal 83. Adapun saran yaitu melaksanakan pentingnya mengenai sosialisasi pedaftaran merek bagi perlindungaan hukum terhadap pemegang merek terhadap meningkat kesadaran bagi pemilik merek untuk mendaftarkaan mereek yang dipakai.
\end{abstract}

Kata Kunci: Perlindungan hukum; Merek; Pemalsuan

\begin{abstract}
Trademark is a form of intellectual property which has a function to increase or smoothen trade in services or goods for those who carry out trade in investment and goods. This study aims to explain legal protection for brand holders against violations of fashion brand counterfeiting and to explain the settlement of legal violations against brand holders who are disadvantaged due to fashion brand counterfeiting. This research uses normative legal research methods, namely doctrinal legal research, also referred to as document library research or document study. The approach used is a statutory and conceptual approach. The data used are primary and secondary legal data sources. The results show that the existing legal protection also applies to brand holders, which is protection provided to legal subjects in the form of both preventive and repressive legal instruments. Legal violations against brand counterfeiting are regulated in Law Number 20 of 2016 concerning Marks and Geographical Indications article 83 paragraph (3), which uses the Commercial court route to become an institution in ending trademark disputes, falsification of famous trademark infringements can be resolved through the criminal legal process and legal channels. civil. Legal efforts to hold brand rights against acts of infringement of Zara's Fashion product brands can file criminal and civil lawsuits against proceedings and / or losses in the dragon court adjusted to the provisions stipulated in article 83.The suggestion is to implement the importance of socializing brand registration for legal protection against Brand holders towards increasing awareness for brand owners to register those used.
\end{abstract}

Keywords: legal protection; Brand; Counterfeiting

\section{PENDAHULUAN}

Era globalisasi menyebabkan hubungan anatara bangsa dan Negara sangatlah luas hal ini dilihat dari berbagai fenomena yang terjadi di belahan dunia dapat diketahui dengan cepat dan tersebarnya berita dengan cepat. Perkembangan zaman akan diikuti oleh canggihnya teknologi, dan kekayaan intelektual semakin hari semakin menarik untuk dibahas dan diteliti dalam perannya mempercepat pergerakan pembangunan nasional. Fenomena kehidupan anata bangsa akan mengakibatkan bergesernya kelakukuan yang merugikan hak orang lain seperti penjiplakan dan 
pembajakan, kelakuan ini tidak akan mendapatkan tempat lagi di dalam masyarakat (Firmansyah, 2001). Hak cipta dan hak kekayaan industry adalah bagian yang utama termasuk dalam HKI (Hak Atas Kekayaan Intelektual) (Sufiarina, 2019). Ruang lingkup anatara kedua bagian ini sangat berbeda yakni dimana hak cipta luas subjeknya dapat ditentukan ataupun diartikan sedangkan hak kekayaan industry tidak dapat ditentukan maupun diartikan secara lugas. Hak atas kekayaan intelektual dalam perjalanannya memiliki aturan guna menghindari pihak lain melakukan perbuatan curang dengan meniru maupun mempergunakan karya seseorang. Salah satu contoh yakni merek, aturan yang mengatur hak atas kekayaan intelektual akan melindungi pemilik merek yang asli dari perbuatan orang lain yang igin mengambil keuntungan dari kesuksesan suatu merek. Pemilik merek dapat melaporkan ke pengadilan dengan meminta agar pihak yang berbuat curang dengan meniru mereknya menyerahkan ganti rugi dari keuntungan yang didapat oleh orang yang berbuat curang dan ganti rugi atas kerugian yang dialaminya (Aridhayandi, 2017).

Promosi barang dan jasa dari suatu perusahaan tertentu dilihat pada mereknya sendiri, dimana hal ini lah yang menjadi pembanding dengan barang dan jasa dari perusahaan lain. Informasi yang ingin disampaikan oleh suatu perusahaan dalam memasarkan dan mengiklankan barangnya memerlukan suatu tanda atau symbol berupa merek (Jened, 2015). Dapat dikatakan bahwa merek dapat dijadikan tameng untuk mengembalikan hak pemiliknya yang telah disalahgunakan oleh pihak lain

Penerapan hukum harus memperhatikan tujuan perlindungan dan titik berat pelanggarannya. Di Indonesia pemalsuan merek, jika kompetitor menampilkan produknya seolaholah produk atau merek tersebut dibuat oleh perusahaan lain. Oleh karena itu, Pasal 372 Kitab Undang-Undang Hukum Pidana (KUHP) tentang persaingan curang dapat dijadikan acuan atau Undang- Undang Nomor 8 Tahun 1999 tentang perlindungan Konsumen bisa diterapkan Baju atau item yang merupakan bagian dari fashion yang sangat diperlukan oleh seluruh orang di dunia.

Dalam dunia fashion terdapat merek guna menjadi tanda pengenal untuk suatu perusahaan dan merek fashion ini sering kali dijadikan lading yang empuk oleh pihak yang berbuat curang demi mendapatkan keuntungan dengan melakukan pelanggaran ha katas merek. Contohnya merek (brand) Zara yang dimana merupakan suatu merek dagang yang terkenal, dan besar yang sudah mengantongi ha katas merek dengan mengikuti prosedur yang telah ditentukan. Brand Zara ini mendaftarkan mereknya tahon 2016 di Kntor Merek sesuai yang tertera pada Undang-Undang Nomor 15 Tahun 2001 tentang Merek.

Dari segi sosial banyak produsen-produsen nakal yang memalsukan merek Zara karena dapat memberikan keuntungan kepada produsen nakal. Penelitian sebelumnya mengungkapkan bahwa Pemegang merek diberi Perlindungan Hukum yang diberikan oleh Undang-Undang Nomor 20 Tahun 2016 mencakup pengaturan bentuk bentuk pelanggaran terhadap merek, sanksi pidana atas pelanggaran terhada merek, dan bisa melaporka melalaui pengadilan Niaga (Mirfa, 2016).

Kriteria pendaftaran merek di Indonesia saat ini amenggunaka sistem konstitutif, sehingga pelaku usaha disarankan agar dengan cepat mendaftarkan merek dagang atau merek jasa ke Direktorat Jenderal Hak Kekayaan Intelektual (Putra, 2014). Menurut Haryadi, (2010) Upaya hukum dapat diberikan oleh para pihak untuk penyelesaian sengketa hak merek adala perdata dan pidana sedangkan ketentuan hukumnya diatur dalam Pasal 90 Undang-undang Nomor 15 Tahun 2001 selain itu juga para pihak dapat menyelesaikan sengketanya melalui badan arbitrase asal sebelumnya telah diperjanjikan. Berdasarkan hal ini dilakukan penelitian dengan tujuan untuk menjelaskan perlindungan hukum bagi pemegang merek terhadap perbuatan pelanggaran pemalsuan merek fashion dan menjelaskan penyelesaian pelanggaran hukom terhadap pemegang merek yang dirugikan akibat pemalsuan merek fashion

\section{METODE PENELITIAN}

Tipe penelitian yang digunakan adalah tipe penelitian hukum normative merupakan penelitian hukum doktrinal, juga disebut sebagai penelitian perpustakaan dokumen atau studi dokumen (Waluyo, 2002). Pendekatan yang digunakan adalah pendekatan konseptual dan pendekatan perundang-undangan. Peneliitian hukum normatif memakai sumber bahan hukum primer, sekunder dan tersier. Bahan hukum primer diperoleh dari peraturan perundang- undangan seperti UndangUndang Dasar Negara Republik Indonesia Tahun 1945, Kitab Undang-Undang Hukum Pidana, Undang-Undang Republik Indonesia Nomor 8 Tahun 1999 tentang Perlindungan Konsumen, 
Undang-Undang Republik Indonesia Nomor 15 Tahun 2001 tentang Merek, Undang-Undang Nomor 20 Tahun 2016 Tentang Merek dan Indikasi Geografis, Undang-Undang Republik Indonesia Nomor 19 Tahun 2002 tentang Hak Cipta, Undang-Undang Nomor 13 Tahun 2016 Tentang Hak Paten. Sumber bahan hukum sekunder diambil dari Buku-buku dan/atau literature, sumber bahan hokum tersier didapat dari surat kabar, kamus hukum majalah dan internet juga dapat digunakan bahan bagi penelitian ini sepanjang memuat informasi yan berkaitan dengan permasalahan ini. Teknik pengumpulan sumber bahan hukum, dilaksanakan dengan cara studi pustaka dan studi dokumen dengan cara mencatat dan membaca informasi seta penjelasan yang berhubungan dengan permasalahan ini, selanjutnya akan dianalisa secara argumentatif yaitu dengan memilah bahan hukum yang kualitasnya dapat menjawab permasalahan tersebut. Kemudian disajikan dengan cara deskriptif analisis dengan menyusun secara sistematik sehingga diperoleh suatu kesimpulan hasil penelitian.

\section{HASIL DAN PEMBAHASAN}

\section{Perlindungan Hukum Bagi Pemegang Merek Terhadap Perbuatan Pelanggaran Pemalsuan Merek Fash}

Merek dapat berbentuk gambar, kata, angka, huruf, nama atau warna-waran yang disatukan menjadi sesuatu yang menarik dan menjadi alat yang membedakan dalam kegiatan berusaha mendagangkan barang ataupun jasa. Merek merupakan tanda yang dimiliki oleh barang terntentu yang dimana namanya dikhususkan untuk suatu perusahaan tertentu saja dan asal dari barang tersebut dijaga agar menjamin kualitas barang guna persaingan dengan perusahaan lain sehingga dapat dibedakan barang produksi perusahaan satu dengan perusahaan lainnya (Soekardono, 1982).

Fungsi merek dalam suatu perusahaan sebagai tanda pengenal untuk membedkan hasil produksi dengan hasil produksi competitor lainnya, sebagai alat promosi, jaminan atas mutu barang, dan penunjuk asal barang yang dihasilkan. Pihak lain yang akan memakai merek yang telah didaftarkan tanpa ijin dari pemiliknya tidak akan dapat menggunakannya karena itu merupakan hak istimewa yang didapatkan oleh pemiik hak atas merek yang telah didaftarkan. Apabila ingin memakai merek suatu brand ternama maka perlu menggunakan cara pertemuan dan melakukan perjanjian resmi dengan pihak pemilik suatu brand lalu perjanjian tersebut didaftarkan di Kantor Merek setempat. Bentuk penyimpangan hak atas merek yang terjadi berupa peniruan atau istilah lainnya pemalsuan merek ini diindikasikan karena pihak yang melakukan pemalsuan tidak meminta izin melakukan perjanjian esmi dengan pemilik brand tersebut (Supramono, 1996).

Pemalsuan merek merupakan perbuatan jahat dalan segi ekonomi, karena barang palsu yang dijual memberikan efek yang merugikan kepada konsumen dan telah membohongi konsumen dengan barang palsu tersebut. Menirukan label atau kemasan suatu barang adalah perilaku yang mirip dengan pemalsuan merek. Perilaku yang dilakukan oleh seseorang ini bukanlah tindakan yang membahayakan hingga menyebabkan kematian namun lebih kepada pesaing yang ingin mencari keuntungan dengan memakai merek yang menyerupai sehingga menimbulkan kebingungan di masyarakat. Perilaku yang dilakukan ini dapat dikenakan saknsi pidana yakni sesuai dengan Pasal 100, 101 dan 102 Undang-Undang Republik Indonesia UU Nomor 20 Tahun 2016 tentang Merek dan Indikasi Geograis.

Pemerintah sudah dari dulu memerhatikan isu perilaku menyimpang yang melibatkan merek di Indonesia. Hal ini dapat dilihat dari adanya Undang- Undang Nomor 15 Tahun 2001 yang telah lama diterbitkan dan disahkan. Bahkan ditahun 2016, pemerintah menerbitkan lagi Undang Undang Nomor 20 Tahun 2016 tentang Merek (UU Merek 2016) yang telah digantikan dengan Undang-Undang No.15 Tahun 2001 (UU Merek 2001). Perlindungan hukum HaKI ialah sistim hukum terdapat unsur-unsur sebagai berikut:

1. Subjek perlindungan yakni pemilik atau pemegang hak, aparat penegak hukum, pejabat pendaftaran dan pelanggaran hukum

2. Objek perlindungan yakni hak merek, hak cipta, hak paten, desain industri, rahasia dagang, tata letak sirkuit terpadu, perlindungan varietas tanaman

3. Perlindungan pendaftaran yang didapatkan dengan menunjukkan sertifikat pendaftaran

4. Jangka waktu perlindungan menurut Undang-Undang Merek 10 (sepuluh) tahun, Hak Paten 20 (dua puluh) tahun, Hak Cipta selama hidup ditambah 50 (lima puluh) tahun setelah meninggal, 
Desain industri 10 (sepuluh) tahun, Varietas Baru Tanaman 20-25 (duapuluh sampai dua puluh lima) tahun.

5. Kegiatan melindungi.

\section{Penyelesaian Pelanggaran Hukom Terhadap Pemegang Merek yang Dirugikan Akibat Pemalsuan Merek Fashio}

Pelanggaran yang terjadi pada merek dapat diselesaikan melalui jalur yang dilakukan dengan cara menyelesaikan di luar persidangan. Bentuk-bentuk ADR (Alernative Dispute Resolution) atau lembaga penyelesaian sengketa yang seperti negoisas, mediasi, konsilasi dan arbitrase dapat digunakan pada kasus perselisihan di bidang hak atas kekayaan intelektual. Namun realitanya setiap permasalahan hak atas kekayaan intelektual yang terjadi lebih banyak diselenggarakan secara perdata dan bukan hukum pidana

Hukum dalam melindungi pemilik merek mempunyai sifat khusus dan monopoli yang artinya disini bahwa perlindungan ini diberikan hanya kepada yang memiliki hak merek dan hak tersebut bias digunakan oleh yang memmilki merek. Apabila kedapatan ada orang lain yang memakai hak merek tanpa seizin pemiliki maka dapat dikatakan bahwa orang tersebut melakukan tindakan melanggar aturan karena orang lain tidak bole memakai merek tanpa adanya ijin dari si pemiliik merek tersebut. Perbuatany yang menyebabkan adanya penyimpangan dari aturan ini berhak diberikan hukuman atau sanksi (Nugroho, 2008). Dalam melindungi pemilih hak merek Undang-Undang Nomor 20 Tahun 2016 menentukan maka Direktorat Jendral Hak Kekayaan Intelektual memiliki tugas dalam memeberikan perlindungan. Setelah merek didaftarkan dan sudah terdaftar barulah hak atas merek tersebut diperoleh, maka apabila ada orang yang dengan gampangnya menjiplak merek si pemilik dapat menggugat orang tersebut secara perdata maupun pidana. Dari perselisihan tersebut Kantor Merek dapat memberi bantuan kepada si pemilik merek untuk menyatakan bahwa merek tersebut benar milik dia dan bantuan yang diberikan secara administrative dengan menunjukan dokumen terkait pendaftaran merek tersebut. Permohonan yang didaftarkan belakangan akan ditolak oleh Kantor Merek karen ditakutkan akan mempunyai itikad tidak baik. Pengadilan yang berhak memeriksa, mengadili dan memutus perselisihan mengenai hak merek adalah Pengadilan Naga, maka pemilik dapat menggugat orang yang tanpa hak melakukan pemalsuan atau penjiplakan merek ke Pengadilan Niga yang dimana adalah badan peradilan khusus

Sanksi pidana yang dapat diberikan kepada para pemalsu berupa pidana kurungan, pidana penjara maupun denda tercantum didalam Undng - Undang Nomr 20 Tahun 2016 tentang Merek dan Indikasi Geograis, pasal 100, 101, dan 102. Pidana penjara yang dikenakan kepada para pemalsu maksimum 5 tahun penjara dan denda terbanya Rp. 2.000.000.000,00 (dua miliar rupiah). Tindk pidana pemalsuan merek terdapat yang misalnya terdapat didalam pasal 100, 101, 102 Undng-Undang Nomr 20 Tahun 2016 yaitu Delik Aduan (klacht delict) bukan yang delik biasa. Penyidik ialah yang memproses tindak pidana perkara pemalsuaan mereek merupakan Penyidik PNS dan Penyidik Kepolisian di Direktorat Jenderal HKI. Selain diatur dalam peraturn undang-undang merek itu sendiri, pelanggaran yang dilakukan seseorang dalam kaitannya dengan merek ditentukan pada KUHP Pasal 382, dan 393.

Pemakaian merek tanpa hak dapat digugat berdasarkan perbutaan melanggar Pasal 1365 KUH Perdata dna sebagai pihak Penggugat wajib membuktikan bahwa ia menderita kerugian akibat prbuatan yang dilakukan oleh tergugat. Didalam pasal 83 ayat(1), ada hukuman perdataa jika seorang melakukn penyimpangan HakMerek. Sehingga pemilik merk bisa menuntut ganti rugi dan dapat menuntut penghentian kegiatan pemalsuan merek tersebut. Ganti rugi disini dapat bersifat materiil maupun inmaterial.

Apabila ingin mengajukan gugatan perdata maka gugatan diajukan kepada pengadilan niaga atau melalui arbitrase atau alternatif penyelesaian sengketa. Alternative penyelesaian sengketa disini bisa negosiasi, mediasi, konsiliasi, dan sebagainya. Apabila ingin mengajukan gugatan pidana, maka gugatan dapat diajukan melalui pengadilan niaga, dan jika dimungkinkan, hakim pengadilan niaga akan mengeluarkan surat penetapan sementara pengadilan, yaitu sebagai upaya pencegahan masuknya barang yang berkaitan dengan pelanggaran hak merek 


\section{SIMPULAN DAN SARAN}

\section{Simpulan}

Berdasarkan hasil analisis data diketahui bahwa Pengaturan perlindungan hukum bagi pemegang merek terhadap perbuatan pelanggaran pemalsuan merek fashion, dimana pengakhiran pelanggaraan hukom terhadap merek yang sudah didaftarkan, terdapat dan diatur pada Pasal 83 ayat (3) UndangUndang Nomur 20 Tahun 2016 tentang Merek dan Indikasi Geogafis dapat dilakukan melaului jalur litigasi yakni mengajukan gugatan perdata ke Pengadilan Niaga setempat, yang kedua Penyelesaian sengketa pemalsuan merek dilakuakn melalui jalur non litigasi yakni dilakuakan di luar pengadilan melalui arbitrase dan alternative lainnya seperti mediasi, konsisliasi, dan negosiasi yang diatur juga dalam pasal 93 dari merujuknya pasal 83 Unddang-Undnag Nomor 20 Tahun 2016 tentng Merek dan Indkasi Geogafis. Dengan ancaman penjara maksimal pidana 5 tahun serta denda maksimalnya $\mathrm{Rp} 2.000 .000 .000,00$.

\section{Saran}

Berdasarkan pembahasan dan simpulan di atas, peneliti dapat memberi saran yaitu Kantor Kementerian Hukum dan Hak Asasi Manusia yang tersebar diseluruh provinsi di Indonesia diharapkan mampu mempermudah, mempercepat jalannya pendaftaran dan memperingan biaya pendaftaran sehingga pemilik merek dapat mendaftarkan dengan cepat dan mendapat perlindungan yang tetap setelah mendaftar mereknya, yang kedua diharapkan kepada konsumen dalam hal ini juga perlu meningkatkan kewaspadaannya dan lebih aktif dalam memerangi barang-barang palsu yang dipasarkan diluar sana jangan hanya diam apabila tau ada barang palsu yang menjiplak suatu merek tertentu, lebih baik melaporkannya kepada pihak yang berwenang jika menemukan pelanggaran yang dilaksanakan oleh orang yang tidak bertanggungjawab.

\section{DAFTAR PUSTAKA}

Aridhayandi, M. R. (2017). Kajian tentang Penerapan Sanksi Pidana terhadap Pelaku yang Melakukan Perbuatan Curang dalam Bisnis Dihubungkan dengan Pasal 379a Kitab Undang-Undang Hukum Pidana. Jurnal Hukum Bisnis Dan Investasi, 8(2), 80-91.

Firmansyah, H. (2001). Perlindungan Hukum terhadap Merek (Panduan memahami dasar hukum penggunaan dan perlindungan merek). Pustaka Yustisia.

Haryadi, R. E. (2010). Perlindungan Hukum Bagi Pemegang Merek terhadap Pelanggaran Merek Menurut UU Merek Indonesia. Jurnal Yuriska, 1(2), 124-131.

Jened, R. (2015). Hukum Merek. Prenadamedia.

Mirfa, E. (2016). Perlindungan Hukum Terhadap Merek Terdaftar. Jurnal Hukum Samudra Keadilan, 11(1), 47-77.

Nugroho, S. A. (2008). Proses Penyelesaian Sengketa Konsumen. Kencana Medua Group.

Putra, F. N. D. (2014). Perlindungan Hukum Bagi Pemegang Hak Atas Merek terhadap Perbuatan Pelanggaran Merek. Hukum Jurnal Ilmu Hukum, 97-108.

Soekardono. (1982). Hukum Dagang Indonesia. Raja Wali.

Sufiarina, S. (2019). Hak Prioritas dan Hak Ekslusif dalam Perlindungan Hki. Jurnal Hukum, 3(2), $265-282$.

Supramono, G. (1996). Pendaftaran Merek. Djambatan.

Waluyo, B. (2002). Penelitian Hukum Praktek. Sinar Grafika. 